\title{
Growth of Non- Performing Assets in Microfinance Institutions: An evidence from India
}

\author{
Shanu Singh ${ }^{1}$, Dr. Chandrama Singh ${ }^{2}$ \\ ${ }^{I}$ (Junior Research Fellow, Department of Applied Economics and Commerce, Patna University, India) \\ ${ }_{2}^{2}$ (Professor, Department of Applied Economics and Commerce, Patna University, India)
}

\begin{abstract}
The evolution of Grameen Bank in Bangladesh helped in the beginning of new era in the industry of microfinance. There are various models under microfinance have been developed so far and one of them is Microfinance Institutions which are the institutions working towards providing finance related services to the people who are deprived from it or find it difficult to receive funds from other sources in order to raise their income levels and improve living standards. MFIs are working towards the demands of financial services and products to meet the consumption and micro-enterprise demands of the poor and rural people. The purpose of the study is to investigate the major trend of nonperforming assets in Microfinance Institutions in India with special reference to the State of Bihar. The research problems include the areas where it is important to understand the prevailing growth trend of NPAs in MFIs and its remedial measures in the long run. The trend of growth in NPAs in Microfinance Institutions working in Bihar has been taken into consideration for rectifying the current norms and conditions of lending which forms the basis of related problems. There are various issues related to the sector of microfinance and MFIs has come up with large number of financial products and services for the people who cannot afford the services from formal financial institutions. Therefore it is important to analyze the progress of such institutions working towards the development of poor and rural people.
\end{abstract}

Key words: Financial services, Microfinance, Nonperforming assets, Training and development, Women empowerment

\section{Introduction}

"When we want to help poor, we usually offer them charity. Most often we use charity to avoid recognizing the problem and finding the solution for it. Charity becomes a way to shrug off our responsibility. But charity is no solution to poverty. Charity only perpetuates poverty by taking the initiative away from the poor. Charity allows us to go ahead with our lives without worrying about the lives of the poor. Charity appeases our consciences."

- Dr. Muhammad Yunus on charity to poor people and their side - effects

There are various cases where poor and rural people do not get funds from financial institutions easily, therefore microfinance came into the picture to provide the capital base to such people so that they can utilize their potential and do something productive to get a livelihood. Poor people are poor not because of the illiteracy alone, there is another side of the story where they do not get capital base to support their livelihood as the retention of returns on labour is also important.

"Once poverty is gone, we will need to build museums to display its horrors to future generations. They'll wonder why poverty continued so long in human society - how a few people could live in luxury while billions dwelt in misery, deprivation and despair."

\section{- Muhammad Yunus on creating a World without poverty}

Poverty is one of the major issues in developing countries and the initiative taken by Muhammad Yunus so far have brought positive changes in the societal development and there is a bright future as well. At the same time there is so much to do in this field which has been given a base by Muhammad Yunus and thus in India, there has been so much done in the field of providing financial services to the poor and rural people with special focus to women population.

\section{Micro Finance in India}

It was started in 1974 in Gujarat as Shri Mahila SEWA (Self Employed Women's Association) Sahakari Bank registered as on urban cooperative Bank. They provided banking services to poor women employed in the organized sector. Microfinance was later evolved in the early 1980s as Self Help Group (SHGs) that provide financial services to the deprived people and therefore it was started in order to fill the gap between poor and rural fund seekers and the availability of funds to them. Most of the Microfinance Institutions came 
into existence in the legal form of trusts and societies and later on so many institutions got registered as NBFCMFIs under a category created by Reserve Bank of India on Malegam Committee recommendations.

\section{Changing Role of Microfinance in Indian Economy}

In India being a developing country, microfinance organizations play a major role in the financial field. They play a major role in providing funds to the businesses and others and thus have accounted for the bulk of the financial intermediation process. Indirectly MFIs also contributed to the process of economic development by credit source to various government agencies, households, and business and to other weaker sections of the society like villages, small scale industries and agriculture as well. The main aim of the paper is to look into the dynamic nature of Micro finance in India with special reference to Bihar and to discuss the relationship between micro finance and Non-Performing assets as what are the incidents and remedial measures (if required) of such NPAs in institutions. All the financing agencies are given below along with the loan disbursed and loan outstanding to MFIs for three consecutive years:

Table 1: Financing agencies with disbursed and outstanding loan to MFIs

\begin{tabular}{|c|c|c|c|c|c|}
\hline \multicolumn{2}{|c|}{ 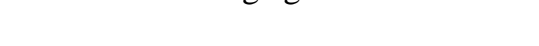 } & \multicolumn{2}{|c|}{ Loans disbursed to MFIs } & \multicolumn{2}{|c|}{ Loans O/S against MFIs } \\
\hline $\begin{array}{c}\text { Financing } \\
\text { Agencies }\end{array}$ & Year & $\begin{array}{c}\text { No. of loan } \\
\text { accounts }\end{array}$ & $\begin{array}{c}\text { Amt (Rs in } \\
\text { crores) }\end{array}$ & $\begin{array}{c}\text { No. of loan } \\
\text { accounts }\end{array}$ & $\begin{array}{c}\text { Amt (Rs in } \\
\text { crores) }\end{array}$ \\
\hline \multirow{3}{*}{$\begin{array}{l}\text { Commercial } \\
\text { Banks }\end{array}$} & 2013-14 & 484 & 9468.83 & 2197 & 14307.57 \\
\hline & 2014-15 & 541 & 13858.64 & 4445 & 18720.61 \\
\hline & $2015-16$ & 564 & 19324.14 & 1561 & 22682.85 \\
\hline \multirow{3}{*}{$\begin{array}{c}\text { Regional Rural } \\
\text { Banks }\end{array}$} & 2013-14 & 16 & 163.18 & 124 & 222.00 \\
\hline & 2014-15 & 15 & 47.69 & 131 & 1186.62 \\
\hline & $2015-16$ & 31 & 52.42 & 344 & 210.23 \\
\hline \multirow[t]{3}{*}{ Cooperative Banks } & $2013-14$ & 4 & 4.48 & 17 & 7.97 \\
\hline & 2014-15 & 0 & 0 & 0 & 0 \\
\hline & $2015-16$ & 3 & 6.00 & 17 & 11.76 \\
\hline \multirow[t]{3}{*}{ SIDBI } & 2013-14 & 41 & 646.01 & 84 & 1979.90 \\
\hline & 2014-15 & 33 & 1283.80 & 86 & 2593.23 \\
\hline & $2015-16$ & 49 & 1413.01 & 98 & 2676.00 \\
\hline \multirow{3}{*}{$\begin{array}{c}\text { Total by all } \\
\text { Agencies }\end{array}$} & 2013-14 & 545 & 10282.49 & 2422 & 1617.43 \\
\hline & 2014-15 & 589 & 15190.13 & 4662 & 22500.46 \\
\hline & $2015-16$ & 647 & 20795.57 & 2020 & 25580.84 \\
\hline
\end{tabular}

Important financing agencies concerned with the area of microfinance are given as:

- Commercial Banks - The number of loan accounts has been increased where as the number of loans outstanding with commercial banks has increased by a higher percentage.

- Regional Rural Banks - The number of loan accounts opened with regional rural banks has been increased in the year 2015-16 in comparison to the years 2014-15 and 2013-14 respectively. The positive aspect is that the outstanding loans with MFIs has been decreased which shows that the MFIs are performing wellenough in the field of providing loans to the borrowers.

- Cooperative banks - Cooperative banks are not actively involved in providing loans to the Microfinance Institutions. Data in the above table shows that the accounts in the year 2014- 15 were nil whereas in the year 2015- 16, it has got increased by a good percentage but at the same time the contribution of cooperative banks is relatively low in comparison to other financial institutions.

- $\quad$ SIDBI - The loan accounts has been increased in the year 2015- 16 in comparison to the year 2014- 15. SIDBI is actively working towards providing funds to the Microfinance Institutions and at the same time loan outstanding with MFIs is also very high.

The banking sector is continuously providing financial assistance to MFIs by way of capital to help them to support poor households and thus enable them for leveraging financial borrowings.

Microfinance Institutions targets women borrowers because most of the rural and marginalized women are not able to fulfill the basic necessities. Women are generally sensitive towards the work and thus put their efforts to achieve the targets of their work. According to a data, the percentage of women borrowers in the Microfinance Institutions has been more than 95 per cent for the years 2013, 2014, 2015 and 2016. The chance of returning the amount along with the interest is comparatively high in case of women population as they keep the account of money and invest according to the need of time and work purpose. The loan disbursement has been continuously increasing over the years and with increasing disbursement, the number of borrowers has increased as well.

There is much more than providing poor people with charity as it would not lead to a developed society. The availability of financial services to them instead would provide a capital base which could help them to become financially independent and stable in the long run. 


\section{Review of literature}

One of the important aspects of the research work is to analyze the works already done in the field of microfinance so that these can form a base for the current study and thus the gap is properly scrutinized.

Rients Jan Galema (2011) talks about the different perspective, instead of looking at debt enforcement from a contracting perspective, it looks at debt enforcement from an institutional perspective. Luther E.Tyson and Mohammad Yunus have given a platform for rural development and income generation by way of Microfinance.

Balaji Sandeep, Park Jiyeon and Widmer Gian Marc (2007) have discussed the outreach of India and China towards the Microfinance in order to form proper income and employment generation base. In case of China, there is no legal aspect in relation to the NGOs working towards the Microfinance perspective whereas in India the system is much more stringent and NGOs are working much more efficiently but still it lacks the ability to reach the poorest section of society due to the people residing in very remote villages.

Kohli (1997) focused on the credit under priority sector that is based on the profitability of commercial banks in India. She basically highlighted the matter of directed credit which cannot be fully blamed for the decreased level of profitability. Therefore, according to Kohli there is a need of re-appraisal of the credit policy in order to understand the root cause of the problem.

Mishra (2003) emphasized on the reasons that caused high rise in gross and net nonperforming assets in the banks. According to him, the cause of NPAs in banks must be taken seriously and the existing setup, banks had to perform well in order to reduce the NPAs as per international standard because the effect of such rise is causing problems for other lending institutions as well.

Malhotra (2002) have developed a list of various dimensions that are linked with women's empowerment such as economic, socio-cultural, interpersonal, legal, political and psychological environment. Thus according to $\mathrm{him}$, these are the frameworks that help women population to strengthen their roles in various dimensions.

There are lots of research papers on nonperforming assets of banks but when it comes to Microfinance Institutions, there are very few papers on the status of nonperforming assets. Thus it is important to analyze such trend of growth for developing states like India where it plays a major role in funding poor and rural people.

\section{Rationale of the Study}

Nonperforming asset is a sensitive issue and must be handled with care by the Microfinance Institutions. The trend of NPAs changes year to year and institutions are effectively taking care of the loans given to borrowers and regulates the overall repayment frequencies. With changing environment, the trend and pattern of providing loans to the borrowers is also changing. In order to comply with the Government policies, Microfinance Institutions are also making necessary changes in their procedures and it is leading to a new funding culture. The scope of study lies in the fact that though the Microfinance is very important aspect in today's competitive economy but at the same time there is a need to understand the trend of nonperforming assets in such Microfinance Institutions as well. The main purpose is to analyze the growth of Microfinance in India in near future and what are the possibilities that it is going to grow to the level presumed by the economist and the government at large. There are large numbers of research papers available on the nonperforming assets and Microfinance Institutions in India as well and therefore the research paper showcases the nonperforming assets of Microfinance Institutions in Bihar, India. It is important to know the trend of growth in nonperforming assets of Microfinance Institutions for future course of action to.

\section{Research questions}

In order to choose and understand the research subject properly, there is a need to ask few questions regarding the validity of the subject matter and how to proceed with the topic. Questions give a framework to the improvement in the situation and how to deal with the different constraints at the same. Few of the research questions that made the work easier and thus on the lines of such questions, research work has been undertaken. They are as follows:

What are the trends of growth in nonperforming assets of various MFIs in Bihar?

What are the conditions of MFIs in Bihar?

How such growth trends affect the MFIs in Bihar?

\section{Objectives of the study}

The need of time is to discuss about the recent trends and changes as well as incidents and reasons (if any) of Non-Performing Assets (NPAs) in Microfinance Institutions (MFIs) in providing funds to loan seekers (if any). Objectives of the research consist of certain factors that can bring new light to the area of nonperforming assets in MFIs that affects the growth of such institutions as well. Some of the points that are identified in order to understand the real problem and thus the major objectives of the research that are discussed and evaluated are as follows: 
1. To study about the major growth trend of Non-Performing Assets in Microfinance Institutions in Bihar.

2. To find out the remedial methods for near future for the growth of MFIs.

3. To provide few suggestions in order to maintain the positive results in the long term.

\section{Hypothesis}

There are few statistical tests has been applied on the following hypothesis in order to understand its acceptance or rejection. On the basis if such tests, it is analyzed whether the null hypothesis is accepted or rejected and thus it gives an idea about the whole study being conducted. The hypothesis for the research work has been formed after considering the subject matter properly. Thus the present pioneer research work is based on the following hypothesis:

Null hypothesis

$\square \quad \mathrm{H} 0=$ There is no difference in growth trend of Non- Performing Assets in Microfinance Institutions in Bihar between any 2 years during the period of study.

Against null hypothesis

$\square \quad \mathrm{H} 1=$ There is difference in growth trend of Non- Performing Assets in Microfinance Institutions in Bihar between any 2 years during the period of study.

\section{Research Methodology}

Research methodology has been selected in such a way that secondary data can be analyzed for concluding the results.

\section{Data collection}

Data collection on the subject matter has been done in the form of secondary data. The source of secondary data where most important data under the category is financial information related to MFIs working in specifically in Bihar which are considered for past six years starting from the year 2011- 12 to 2016-17 for the purpose of testing the hypothesis.

\section{Population and Sampling}

Population under the research paper is all the MFIs working in one of the States of India that is Bihar and the number of MFIs is limited to34 in Bihar which is registered under various acts till the financial year 2016-17 whereas random sampling has been done from the population of these MFIs.

The figures related to profits and nonperforming assets of various MFIs working in Bihar are selected randomly for the purpose of understanding their financial progress and the percentage growth trend of NPAs has been taken in relation to all MFIs working in Bihar.

\section{Explanation of the variable}

Variables taken into consideration for the purpose of analyzing the research problem and understanding the real cause of the underlying issue:

Nonperforming assets - It is a variable which has been studied in the research paper where NPAs has been taken as the variable as it plays an important part in the growth of MFIs. The nonperforming assets have been discussed in the light of MFIs selected randomly for the analysis purpose taking into account the consolidated figures of all the branches of MFIs taken together. One of the burning issues in the economy is trend of growth of nonperforming assets in the Microfinance Institutions in India with a special reference to Bihar. Though some of the surveys show that the nonperforming assets are on a rise from the year 2010 till today but at the same time there are few institutions which are not making any losses.

The analysis is made on the basis of financial information furnished from the various reports related to Microfinance Institutions working in Bihar and thus it is based on the secondary data. Nonperforming assets is the main aspect for testing the hypothesis of the research work where the growth trend of nonperforming assets have been considered for different Microfinance Institutions in Bihar.

\section{Data analysis}

In order to know the growth of NPAs of sample MFIs between any two years, paired t- test has been used. There are total 15 pairs used for analyzing the growth under paired t- test. In order to analyze the test, following hypothesis has been formulated as mentioned previously in the hypothesis section. The data analysis has been made with the help of paired t-test by taking into account all the different pairs of two years respectively. The sample size in 17 and therefore it is a small sampling and therefore paired t- test has been used. 


\section{Paired t- test}

The main purpose of paired t- test is to determine if there is any statistical evidence about the mean difference between paired observations where the outcome is significantly different from zero. Here paired t- test has been used to understand the significance of different pairs formed and thus to test the hypothesis.

(a) Paired samples statistics

Table 2: Paired Samples Statistics

\begin{tabular}{|ll|r|r|r|r|}
\hline & & Mean & $\mathrm{N}$ & Std. Deviation & Std. Error Mean \\
\hline \multirow{2}{*}{ Pair 1 } & Year_2013 & 1.17000 & 17 & .494280 & .119880 \\
& Year_2012 & 1.18235 & 17 & .224737 & .054507 \\
Pair 2 & Year_2014 & 1.09700 & 17 & .421688 & .102274 \\
& Year 2013 & 1.17000 & 17 & .494280 & .119880 \\
Pair 3 & Year_2015 & .93176 & 17 & .352087 & .085394 \\
& Year_2014 & 1.09700 & 17 & .421688 & .102274 \\
Pair 4 & Year_2016 & .32276 & 17 & .557919 & .135315 \\
& Year 2015 & .93176 & 17 & .352087 & .085394 \\
Pair 5 & Year_2017 & .09724 & 17 & .192220 & .046620 \\
& Year 2016 & .32276 & 17 & .557919 & .135315 \\
Pair 6 & Year_2014 & 1.09700 & 17 & .421688 & .102274 \\
& Year22012 & 1.18235 & 17 & .224737 & .054507 \\
Pair 7 & Year_2015 & .93176 & 17 & .352087 & .085394 \\
& Year_2012 & 1.18235 & 17 & .224737 & .054507 \\
Pair 8 & Year_2016 & .32276 & 17 & .557919 & .135315 \\
& Year 2012 & 1.18235 & 17 & .224737 & .054507 \\
Pair 9 & Year_2017 & .09724 & 17 & .192220 & .046620 \\
& Year 2012 & 1.18235 & 17 & .224737 & .054507 \\
Pair 10 & Year_2015 & .93176 & 17 & .352087 & .085394 \\
& Year_2013 & 1.17000 & 17 & .494280 & .119880 \\
Pair 11 & Year_2016 & .32276 & 17 & .557919 & .135315 \\
& Year 2013 & 1.17000 & 17 & .494280 & .119880 \\
Pair 12 & Year_2017 & .09724 & 17 & .192220 & .046620 \\
Pair 13 & Year 2013 & 1.17000 & 17 & .494280 & .119880 \\
& Year_2016 & .32276 & 17 & .557919 & .135315 \\
Pair 14 & Year_2014 & 1.09700 & 17 & .421688 & .102274 \\
& Year_2017 & .09724 & 17 & .192220 & .046620 \\
& Year 2014 & 1.09700 & 17 & .421688 & .102274 \\
& Year_2017 & .09724 & 17 & .192220 & .046620 \\
& Year_2015 & .93176 & 17 & .352087 & .085394 \\
\hline \multirow{5}{*}{ Pear }
\end{tabular}

Overall 15 different pairs of 6 years have been made for the purpose of analyzing the paired t- test. The above table shows the mean value and standard deviation of each year which have been explained in one- way ANOVA test as well. This gives a general view about the various pairs made out of 6 years of sample MFIs. So mean is highest for the year 2011- 12 with the value of 1.18335 and standard deviation is highest with the value of 0.557919 for the year 2015- 16 .

\section{(b) Paired samples correlation}

Table 3: Paired Samples Correlations

\begin{tabular}{ll|r|r|r|}
\hline & & N & Correlation & Sig. \\
\hline Pair 1 & Year_2013 \& Year_2012 & 17 & .137 & .599 \\
Pair 2 & Year_2014 \& Year_2013 & 17 & .495 & .043 \\
Pair 3 & Year_2015 \& Year_2014 & 17 & .445 & .074 \\
Pair 4 & Year_2016 \& Year_2015 & 17 & .222 & .392 \\
Pair 5 & Year_2017 \& Year_2016 & 17 & .213 & .412 \\
Pair 6 & Year_2014 \& Year_2012 & 17 & -.063 & .810 \\
Pair 7 & Year_2015 \& Year_2012 & 17 & .260 & .313 \\
Pair 8 & Year_2016 \& Year_2012 & 17 & .711 & .001 \\
Pair 9 & Year_2017 \& Year_2012 & 17 & .630 & .007 \\
Pair 10 & Year_2015 \& Year_2013 & 17 & .471 & .057 \\
Pair 11 & Year_2016 \& Year_2013 & 17 & .622 & .008 \\
Pair 12 & Year_2017 \& Year_2013 & 17 & -.038 & .885 \\
Pair 13 & Year_2016 \& Year_2014 & 17 & .148 & .570 \\
Pair 14 & Year_2017 \& Year_2014 & 17 & -.171 & .511 \\
Pair 15 & Year_2017 \& Year_2015 & 17 & .525 & .030 \\
\hline
\end{tabular}

As per the table above, the correlation is highest for the pair 8 which consists of year 2016 and 2012 with the value of 0.711 that shows high level of positive correlation between the years 2012 and 2016. This shows that both are moving in the same directions as the percentage trend of nonperforming assets has 
increased. Under the table of paired samples correlations, the results are significant only for five pairs out of 15 pairs, namely pair 2 (years $2014 \&$ 2013), pair 8 (years $2016 \&$ 2012), pair 9 (years $2017 \&$ 2012), pair 11 (years 2016 and 2013) and pair 15 (years 2017 and 2015) while talking about the correlation factor. There is no significant correlation in other pairs in the period of study.

(c) Paired samples test

Table 4: Paired Samples Test

\begin{tabular}{|c|c|c|c|c|c|c|c|c|c|}
\hline & \multicolumn{5}{|c|}{ Paired Differences } & \multirow[t]{3}{*}{$\mathrm{t}$} & \multirow[t]{3}{*}{ df } & \multirow{3}{*}{$\begin{array}{l}\text { Sig. (2- } \\
\text { tailed) }\end{array}$} \\
\hline & & \multirow[t]{2}{*}{ Mean } & \multirow[t]{2}{*}{$\begin{array}{c}\text { Std. } \\
\text { Deviation }\end{array}$} & \multirow[t]{2}{*}{$\begin{array}{l}\text { Std. Error } \\
\text { Mean }\end{array}$} & \multicolumn{2}{|c|}{$\begin{array}{c}95 \% \text { Confidence Interval } \\
\text { of the Difference }\end{array}$} & & & \\
\hline & & & & & Lower & Upper & & & \\
\hline Pair 1 & $\begin{array}{l}\text { Year_2013 - } \\
\text { Year_2012 }\end{array}$ & -.012353 & .514095 & .124686 & -.276676 & .251971 & -.099 & 16 & .922 \\
\hline Pair 2 & $\begin{array}{l}\text { Year_2014 - } \\
\text { Year_2013 }\end{array}$ & -.073000 & .464343 & .112620 & -.311743 & .165743 & -.648 & 16 & .526 \\
\hline Pair 3 & $\begin{array}{l}\text { Year_2015 - } \\
\text { Year_2014 }\end{array}$ & -.165235 & .412014 & .099928 & -.377074 & .046603 & -1.654 & 16 & .118 \\
\hline Pair 4 & $\begin{array}{l}\text { Year_2016 - } \\
\text { Year_2015 }\end{array}$ & -.609000 & .589934 & .143080 & -.912316 & -.305684 & -4.256 & 16 & .001 \\
\hline Pair 5 & $\begin{array}{l}\text { Year_2017 - } \\
\text { Year_2016 }\end{array}$ & -.225529 & .550056 & .133408 & -.508342 & .057283 & -1.691 & 16 & .110 \\
\hline Pair 6 & $\begin{array}{l}\text { Year_2014 - } \\
\text { Year_2012 }\end{array}$ & -.085353 & .490170 & .118884 & -.337375 & .166669 & -.718 & 16 & .483 \\
\hline Pair 7 & $\begin{array}{l}\text { Year_2015 - } \\
\text { Year_2012 }\end{array}$ & -.250588 & .365042 & .088536 & -.438276 & -.062901 & -2.830 & 16 & .012 \\
\hline Pair 8 & $\begin{array}{l}\text { Year_2016 - } \\
\text { Year_2012 }\end{array}$ & -.859588 & .428254 & .103867 & -1.079776 & -.639400 & -8.276 & 16 & .000 \\
\hline Pair 9 & $\begin{array}{l}\text { Year_2017 - } \\
\text { Year_2012 }\end{array}$ & -1.085118 & .181687 & .044066 & -1.178533 & -.991703 & -24.625 & 16 & .000 \\
\hline Pair 10 & $\begin{array}{l}\text { Year_2015 - } \\
\text { Year_2013 }\end{array}$ & -.238235 & .452220 & .109679 & -.470745 & -.005725 & -2.172 & 16 & .045 \\
\hline Pair 11 & $\begin{array}{l}\text { Year_2016 - } \\
\text { Year_2013 }\end{array}$ & -.847235 & .461216 & .111861 & -1.084370 & -.610100 & -7.574 & 16 & .000 \\
\hline Pair 12 & $\begin{array}{l}\text { Year_2017 - } \\
\text { Year_2013 }\end{array}$ & -1.072765 & .537111 & .130269 & -1.348922 & -.796607 & -8.235 & 16 & .000 \\
\hline Pair 13 & $\begin{array}{l}\text { Year_2016 - } \\
\text { Year_2014 }\end{array}$ & -.774235 & .647567 & .157058 & -1.107184 & -.441287 & -4.930 & 16 & .000 \\
\hline Pair 14 & $\begin{array}{l}\text { Year_2017 - } \\
\text { Year_2014 }\end{array}$ & -.999765 & .492504 & .119450 & -1.252987 & -.746542 & -8.370 & 16 & .000 \\
\hline Pair 15 & $\begin{array}{l}\text { Year_2017 - } \\
\text { Year_2015 }\end{array}$ & -.834529 & . 299771 & .072705 & -.988657 & -.680402 & -11.478 & 16 & .000 \\
\hline
\end{tabular}

In the above table, there are 15 pairs of different combinations of 6 years. Following are the explanations for different pairs:

From the above table of paired t- test, the significance level of various pairs can be analyzed. Pair 1 (years 2013 \& 2012), Pair 2 (years 2014 \& 2013), Pair 3 (years 2015 \& 2014), Pair 5 (years 2017 \& 2016) and Pair 6 (years $2014 \&$ 2012) shows that there is no significance difference between the growth trend of nonperforming assets of sample MFIs in Bihar as the significant value is more than 0.05 .

$\square$ Pair 4 (years 2016 \& 2015) - The significant value is less than 0.05 and therefore there is a level of significance in pair 4 and thus null hypothesis is rejected and alternative hypothesis is being accepted.

$\square$ Pair 7 (years 2015 \& 2012) - The significant value is less than 0.05 and therefore there is a level of significance in pair 7 and thus null hypothesis is rejected and alternative hypothesis is being accepted.

$\square$ Pair 8 (years 2016 \& 2012) - The significant value is less than 0.05 and therefore there is a level of significance in pair 8 and thus null hypothesis is rejected and alternative hypothesis is being accepted.

$\square$ Pair 9 (years $2017 \&$ 2012) - The significant value is less than 0.05 and therefore there is a level of significance in pair 9 and thus null hypothesis is rejected and alternative hypothesis is being accepted.

$\square$ Pair 10 (years 2015 \& 2013) - The significant value is less than 0.05 and therefore there is a level of significance in pair 10 and thus null hypothesis is rejected and alternative hypothesis is being accepted.

Pair 11 (years $2016 \& 2013$ ) - The significant value is less than 0.05 and therefore there is a level of significance in pair 11 and thus null hypothesis is rejected and alternative hypothesis is being accepted.

$\square$ Pair 12 (years 2017 \& 2013) - The significant value is less than 0.05 and therefore there is a level of significance in pair 12 and thus null hypothesis is rejected and alternative hypothesis is being accepted.

$\square$ Pair 13 (years 2016 \& 2014) - The significant value is less than 0.05 and therefore there is a level of significance in pair 13 and thus null hypothesis is rejected and alternative hypothesis is being accepted. 
$\square \quad$ Pair 14 (years 2012 \& 2014) - The significant value is less than 0.05 and therefore there is a level of significance in pair 14 and thus null hypothesis is rejected and alternative hypothesis is being accepted. Pair 15 (years 2017 \& 2015) - The significant value is less than 0.05 and therefore there is a level of significance in pair 15 and thus null hypothesis is rejected and alternative hypothesis is being accepted.

10 out of 15 pairs show that the test is significant at 5 per cent level and thus alternative hypothesis is being accepted. As per paired t- test, there is difference between the average growths of nonperforming assets of sample Microfinance Institutions between any two years of the given period of study. There are 10 pairs which show that there is a difference between average growths of NPAs in MFIs but as per the mean value, the growths have been negative. The negative mean and the negative $t-$ value in the above table shows the negative growth of NPAs in sample MFIs. Therefore as per the paired t- test results, the alternative hypothesis has been accepted and null hypothesis has been rejected which means that there is difference between average growths of nonperforming assets between two years during the period of study. Thus, after the small sample paired t- test, it is analyzed that there is a difference in the growth trend of nonperforming assets in Microfinance Institutions in Bihar as the percentages of NPAs have been different for different years. At the same time, the negative average difference in mean value suggests that there is a negative growth in the NPAs or there is decline in the nonperforming assets in MFIs and therefore it is favorable for the Microfinance Institutions working in Bihar for the development and growth in the near future as well.

\section{VII.Conclusion and Recommendations}

The proper analysis has been made for all the information related to the study area and Microfinance Institutions working in Bihar region. Studying about nonperforming assets has added value to the image of microfinance sector in Bihar as the results are positive where there is a growth of nonperforming assets in Microfinance Institutions which is in a negative direction and that gives an idea about the growth and development of such institutions in Bihar. The government has also supported MFIs to a great extent so that poor and rural people who are not able to receive funds from formal financial institutions can receive it from the Microfinance Institutions channel. There is no growth in the positive trend of nonperforming assets in the Microfinance Institutions working in the State of Bihar. Therefore there is downward growth or decline in the nonperforming assets in the Microfinance Institutions in Bihar.

\section{To the Microfinance Institutions}

\section{Recommendations}

Following are few points that MFIs must take into consideration in order growth and development of MFIs in Bihar:

a) Investment education must be provided to the loan seekers so that they can utilize the loans properly in a profitable way.

b) Training and development should be provided to the borrowers in more appropriate way so that they can utilize the funds properly in productive areas.

c) Interest rate should be according to the amount of loan and the kind of investment proposal so that profitable ventures can pay back the loan amount on the fixed time.

d) MFIs should prefer group loans over individual loans because the risk of nonpayment reduces in group loans.

Though MFIs are providing funds to the poor and needy people and doing a commendable job but at the same time in order to increase the productivity of the institutions and therefore reducing the level of nonperforming assets in MFIs, some of the suggestions can be provided to MFIs. These suggestions are based on the direct interaction with the borrowers and how do they actually feel about the prevailing scenario in microfinance industry and solutions that can increase the growth of Microfinance Institutions in the State of Bihar. The suggestions can be summarized as follows:

$\square \quad$ There are more in- depth analysis required to understand the investment and diversification plans of the borrowers.

$\square \quad$ Group lending can reduce the rate of nonperforming assets in the Institutions as groups behave more rationally in comparison to individuals.

$\square \quad$ There should be some reforms in the lending process and requirement of collateral securities must be considered once again in order to provide better facilities to the borrowers.

$\square$ Training and development facilities provide a base to the borrowers for making productive investments and proper diversification of funds so that risk factor is taken care of.

$\square \quad$ Registrations of MFIs should be taken seriously and thus the transparency must be achieved in the lending process.

$\square \quad$ There should be proper documentations available with the MFIs and duplication of loans must be avoided by keeping a track of all genuine borrowers. 


\section{To the borrowers of MFIs}

The customers should be well aware about the uses of loan amount because once they are provided with loans; they should invest that in some more productive area so that it can be profitable. The most important reason for negligence in paying back the loan amount by the customers is that they don't use the amount for profitable ventures, therefore MFIs and other social welfare agencies must provide proper information to the customers related to the investments and business proposals.

It is really hard to understand the real situation of the borrowers at large. Because of the presence of diversified populated and their related problems. Though it is the duty of Microfinance Institutions to manage the funding process and its related issues but at the same time, there are certain issues which must be taken care of by the borrowers as well. The suggestions are as follows:-

a) Borrowers should try not to take funds for unproductive purposes because this would definitely not be able to generate any income and ultimately they appear in the list of defaulters. In such situations it becomes difficult to apply for funds again.

b) Whether Microfinance Institution asks for the diversification plans from the borrowers or not but it is appreciable if the borrowers do consider the investments and it relates diversification plans properly so that the risk factor is reduced.

c) Instead of blaming the MFIs for not providing proper training and development facilities, the borrowers should try to understand the market situations and its related demands by interacting with other groups of people already engaged in the activities with the help of Microfinance Institutions.

\section{Limitations}

The limitation shows the boundaries under which the research work have been carried out in order to understand the results of the survey. It is practically not possible to take into consideration all the variables that affect the Microfinance Institutions working in India and therefore it includes certain limitations as well. Such limitations of the study have been given below in order to draw a boundary of the research work done to make it less complicated:

$\square$ The study is based on the data related to Microfinance Institutions working in one of the States of India that is Bihar.

$\square$ MFIs are working at a very small scale in comparison to the public and private sector banks and other models of microfinance industry, so the proper financial statements are not generally available to the public. So the collection of secondary data had been a struggle too.

No research work can be made by taking into account all the variables of a population and at the same time there is a time limit to the work as well. Therefore there are certain limitations of this research work as well which are discussed and pointed out as follows:

1. Area of Study - The study is limited to the one aspect of microfinance that is Microfinance Institutions in Bihar. The scope of microfinance is diversified and thus here area is limited to only institutions.

2. Period of study - The period of study is six years starting from the financial year 2011- 12 to the financial year 2016- 17.

3. Numbers of Institutions - There are 166 Microfinance Institutions are currently working in India whereas only 34 are working in Bihar and the sample size has been taken as 17 MFIs fromBihar.

4. Data from Institutions - The data collected from Microfinance Institutions are in the form of secondary data. Therefore the research is based on the secondary data only.

Therefore the research problem lies in the following points where proper analysis has been made on these points:

$\square$ There is no literature available in this area of microfinance that is no research papers are available on nonperforming assets of Microfinance Institutions which makes this topic a little more challenging.

Only financial statement analysis of MFIs for the purpose of understanding NPAs is not sufficient enough for generating an idea of the current scenario and its related problems.

\section{Scope for the future study}

A lot has been done in the research paper but still there is scope for future study. The growth in the number of Microfinance Institutions in India is fairly good in recent years but still there is scope for more to be done. According to a report, there are large numbers of unregistered MFIs working in different States of India and with increasing transparency requirements by the Government, more unregistered MFIs are getting registered now. Therefore, in the upcoming years, more MFIs would be getting registered under the purview of Government and more detailed analysis of financial statements can be made in few years from now. The study can be done on performance evaluation of MFIs with more number of MFIs covered in India. In this research paper, nonperforming assets has been given the priority to analyze the performance of MFIs but it is just one 
part of finance and thus proper financial statements can be taken into account for in-depth knowledge of their workings along with the perspectives' of borrowers.

Therefore scope for future study is wide and proper knowledge can be applied in order to conclude the workings of MFIs in India. Performances can be analyzed for different States and especially for underdeveloped States in India where scope for development and growth is huge. Research gives a wide variety of related topics which can be undertaken by researchers for the analysis of the workings and its environment.

Some of the areas are summarized where related research can take place and they are as follows:

$\square$ Studying the nonperforming assets of MFIs in different States of India along with considering the outlook of borrowers as well.

Instead of nonperforming assets, financial statements as a whole can be utilized to understand the performance of different MFIs working in India.

$\square$ MUDRA can be incorporated in order to understand the performance after its entry in microfinance sector. The performance of MUDRA can be analyzed only after few years as it is very new and measurement of performances becomes a bit difficult in the current economy.

$\square$ Comparative analysis of benefits and problems of MFIs and SHGs, JLGs can provide help in understanding the real situation and the way for its improvement in India

\section{References}

[1] Pavanch, P.K. (2009). Performance of Banking Industry in India. Retrieved from http://www.termpaperwarehouse.com/

[2] Sa-Dhan (2009-10), 'Bharat Microfinance Report - Strenthening the Provision of Microfinance Services in India - 2010', the Association of Community Development Finance Institutions', New Delhi.

[3] Sa-Dhan (2010-11), 'Bharat Microfinance Report - Strenthening the Provision of Microfinance Services in India - 2011', the Association of Community Development Finance Institutions', New Delhi.

[4] Sa-Dhan (2011-12), 'Bharat Microfinance Report - Moving the sector towards Self- Regulation- 2012', the Association of Community Development Finance Institutions', New Delhi

[5] Sa-Dhan (2012-13). 'Bharat Microfinance Report - Deepening the engagement of Microfinance in Inclusive growth', the Association of Community Development Finance Institutions', New Delhi

[6] Sa-Dhan (2013-14), 'Bharat Microfinance Report - Strenthening Financial Inclusion - 2015', Sa-Dhan, the Association of Community Development Finance Institutions', New Delhi.

[7] Sa-Dhan (2014-15), 'Bharat Microfinance Report - 2015', Sa-Dhan, The Association of Community Development Finance Institutions', New Delhi.

[8] Sa-Dhan (2015-16), 'Bharat Microfinance Report - 2015', Sa-Dhan, the Association of Community Development Finance Institutions', New Delhi.

[9] David A. Schauer, Dennis L. Soden.(2001) "Capital Access in EI Paso: A multivariate analysis of factors influencing loan Approval", IPED technical reports.

[10] Dr. P.K. Srivastava.(2007). "Banking theory and practice", Himalaya Publishing House, Tenth revised edition.

[11] Nalini Prava Tripathy.(2005).Emerging Scenario of Indian banking Industry. Mahamaya Publication.

\section{Key words}

\section{Financial services}

Financial services are the services which are provided to the people for proper management of funds and assets at a wider range in order to make them invest in a productive way that can bring financial benefits and returns in the future.

\section{Microfinance}

Microfinance refers to providing short term funds to the rural and poor people who cannot afford the formal financial institutions to get funds in order to fulfill their financial requirements for various productive and nonproductive purposes.

\section{Nonperforming assets}

When the borrowers fail to return back the principal and interest amount on time, it is classified as nonperforming assets. Non-performing Assets (NPAs) are a major concern for banks and other financial institutions in India. It is one of the best indicators of financial health of financial institutions.

\section{Training and development}

Borrowers of Microfinance Institutions are provided proper training and development facilities in order to ensure utilization of funds by them in productive purposes so that they can earn regular income and thus become financially independent.

\section{Women empowerment}

Women empowerment is one of the important issues for the development of the society and it refers to the provision of equal rights to the women population of the country so that they can enjoy equal rights to control and receive benefits from the resources, assets, income and thus maintain their economic status and well being. 